JOURNAL OF AKSARAY COMMUNICATION

Cilt 4, Sayı 1, Ocak 2022 - Volume:4 Issue:1, January 2022

e-ISSN 2667-6168

http://dergipark.gov.tr/aid

Araştırma Makalesi/ Research Article

Doi: 10.47771/aid.1030762 Ikilem (Social Dilemma) Netflix Belgesel Filminin Analizi. Aksaray İletişim Dergisi, 4(1), 21-45. doi:10.47771/aid.1030762

Kabul Tarihi/ Accepted: 30.01 .2022 Yayın Tarihi/Published: 31.01 .2022

\title{
Sosyal Medyaya Eleştirel Bir Bakış: Sosyal İkilem (Social Dilemma) Netflix \\ Belgesel Filminin Analizi
}

Tarık PULURLUOĞLU1

\section{Öz}

Son yıllarda internet, bilgisayar, akıllı telefon ve televizyon gibi, yeni medya teknolojilerinin yoğun olarak kullanıldığı bir dönem içerisinde yaşanmaktadır. Tüm bu teknolojilerin hizla popülarite kazanmasıyla birlikte günümüzde sosyal ilişkiler, bireysel yaşam ve özellikle de aile içi ilişkiler dönüşüme uğramıştır. Sosyal medya kavramını hayatımıza kazandıran yeni medya teknolojileri toplumsal hayatın her bir safhasında kendisine yer edinerek, insanların hayatların etkilemekte, dönüştürmekte, yaşam tarzlarında ve gündelik hayatlarında derin izler bırakmaktadır. Bu çalışmada ilk olarak sosyal medya kavramı ve sosyal medya bağımlılığına değinilmiş, daha sonra ilgili eleştirel kuramlar çerçevesinde göstergebilimsel analiz yöntemi kullanılarak Netflix dijital platformu tarafından 2020 yılında yayımlanan "Sosyal İkilem" adlı belgesel film ile ilgili analiz ve değerlendirmelere yer verilmiştir. Yapılan değerlendirmeler sonucunda gelişen iletişim teknolojileri ve sosyal medya ortamlarının bilinçli kullanılmadı̆̆ takdirde bilhassa gençler üzerinde psikolojik ve sosyal anlamda çok çeşitli problemlere sebebiyet verdiği bulgulanmıştır.

Anahtar Kelimeler: Sosyal İkilem, Sosyal Medya, Sosyal Medya Bağımlılığı, Eleştirel Kuram, Göstergebilim, Netflix

\footnotetext{
1 Yüksek Lisans Öğrencisi, Aksaray Üniversitesi, Sosyal Bilimler Enstitüsü, iletisim Bilimleri, tarikpulurlu@gmail.com ORCID: 0000-0003-1666-2044
} 


\title{
A Critical Approach to Social Media: Social Dilemma Analysis of Netflix Documentary Film
}

\begin{abstract}
In recent years, we have been living in a period in which new media technologies such as internet, computer, smart phone and television are used intensively. With the rapidly gaining popularity of all these technologies, social relations, individual life and especially interfamilial have been transformed today. New media technologies that brings the concept of social media to our lives; by taking a place in each stage of social life, it influences and transforms people's lives and engrave in their lifestyles and daily lives.

In the present study, firstly, the concept of social media and social media addiction were mentioned hen using the indicative analysis method within the framework of relevant critical theories analysis and evaluations related to the documentary film "Social Dilemma", which was released by Netflix digital platform in 2020, were included. As a result of the evaluations, it has been determined that if the developing communication technologies and social media environments are not used consciously, they cause a wide variety of psychological and social problems, especially on young people.
\end{abstract}

Keywords: Social Dilemma, Social Media Addiction, Critical Theory, Semiology, Netflix

\section{Giriş}

Son yillarda çocuklar yeni medya teknolojilerinin yoğun olarak kullanıldı̆̆ kültürün içerisine doğmakta, "Dijital Kültür" olarak adlandırılan bu kültürün içerisinde büyümekte ve yine bu kültürün hayatımıza kazandırdığı teknolojik araçları kullanarak sosyalleşmektedirler. Bireylerin aile içi ve sosyal ilişkileri ise yaşanan bu kültürel dönüşüm sürecinden kayda değer biçimde etkilenmektedir. Marshall McLuhan'ın küresel köy benzetmesi bugünlerde ilgi çeken oyunlar ve araçlar sayesinde birdenbire gerçek zamanlı bir olguya dönüşmüştür. Eskiden sokakta oynadıkları oyundan akşam yemeğine zorla çağırılan çocuklar, şimdi ise bilgisayar ekranı başındaki oyundan yemeğe çağrılmaya başlanmışlardır. Geçmişte "dışardan eve girmiyor" diye eleştirilen çocuk, günümüzde ise "odasından dişarı çıkmıyor"e söylemleriyle eleştirilmeye başlanmıştır (İdris, 2017, s. 599). Gençlik dönemi çeşitli sorunların gün yüzüne çıktığı bir dönemdir. Ergenlik dönemini ve sonrasını içine alan bu süreç aslında insan hayatının en önemli dönemlerinden birisidir. $\mathrm{Bu}$ dönmedeki bazı anlayışlar yetişkinlikte de kalıcı etkiler meydana getirmektedir. Tarihsel süreçte sinema ile başlayan televizyon ile devam eden bilgisayarlar ve cep telefonları ile zirve yapan sanal âleme bağımlılık günümüz gençliğinin temel sorunu olarak karşımıza çıkmaktadır (Atak, 2020, s. 200). Yeni teknolojiler gençlere devamlı olarak sosyal medya güncellemeleri, izlenebilecek sayısız video, oldukça sürükleyici ve ilgi çekici birçok dijital oyun içerikleri sunarak onların boş vakitlerini değerlendirme süreçlerinde de değişim yaşanmasına sebep olmuştur. Anne babaların 
önemli bir kısmı bu değişikliklerin çocukları açısından olumlu yönde olmadı̆̆ından endişe duymakta ve çocukların ekran karşısında harcadıkları uzun sürelerin onları hem kendilerinden hem de sosyal çevrelerinden kopartarak depresyona sürüklediğinden yakınmaktadırlar (Unicef, 2017, s. 25).

Twenge tarafından "internet nesli" olarak adlandırılan 1995 yılından sonra doğan çocuklar da kendilerinden önceki nesillerde hiç rastlanmamış düzeylerde davranış bozuklukları bulgularına rastlanmaktadır. Bu internet neslinin; davranışları, boş zamanı değerlendirme biçimleri, dini ve manevi eğilimleri, cinsellikle ilgili tutumları, sosyal ve siyasi etkinliklere katılımları gibi pek çok olgunun geçmiş kuşaklarla kıyaslandığında tamamen farklılık gösterdiği görülmektedir. Z kuşağı olarak da bilinen bu dönemin çocukları, son yıllarda görülmüş en tehlikeli psikolojik problemler ile yüz yüze gelmektedirler. 2011-2012 yılından itibaren (ABD'de cep telefonunun yaygınlaşmaya başladığ 1 tarih) kaygı, depresyon ve intihar oranlarındaki ciddi düzeyde artış bir bakıma ebeveynlerin yaşadıkları endişelerin haklılık payını gözler önüne sermektedir (Atak, 2020, s. 200-201).

Tüm bu bilgiler ışığında yapılan çalışmanın amacı, Netflix tarafından hazırlanıp 2020 yılında izleyiciyle buluşturulan "Sosyal İkilem" (Social Dilemma) belgeselini göstergebilimsel analiz yöntemini kullanarak incelemek ve belgesel içerisindeki alt metinleri görünür hale getirebilmektir.

\section{Sosyal Medya Kavramı}

Kişilerarası iletişimin bir özgürlük alanı olarak bahsedildiği günümüz toplumunda, sıradan insanın binlerce bireye doğrudan ulaşabilmesinin geçmişteki gibi korku yaratmadığı ve imkânsız olarak görülmediği bir dönem içerisinde yaşamaktayız. Literatürde "Yeni Medya veya Dijital Medya" çağı olarak adlandırılan bu dönemle birlikte, Mcluhan’ın bahsettiği dünyanın küresel bir köye dönüşme süreci de hız kazanmıştır. Yeni medya teknolojileri tüm dünya toplumları arasında kilometrelerle ifade edilen mesafe kavramını ortadan kaldırarak; toplumları, kültürleri ve onların içerisinden geldikleri gelenekleri "sosyal medya" adı altında yeni bir sanal dünya içerisinde buluşturarak toplumları birbirlerine yakınlaştırmıştır.

Sosyal medya, yeni medya teknolojilerinin hızlı yükselişi neticesinde bilinirliğini arttırmış ve iletişim sektöründe büyük bir değişim yaşanmasına sebep olmuştur. Basit bir biçimde tanımlamak gerekirse sosyal medya; "bireyin kendi çabası sonucunda ortaya çıkardığı çok çeşitli içerikleri yeni medya teknolojileri aracılığıyla başkalarıyla paylaştı̆̆ı platformlara verilen genel isim" şeklinde ifade edilebilir. Sosyal medya platformlarını geleneksel medya ortamlarından ayıran en belirgin özellik olarak kullanıcılar arası etkileşime imkân tanıması söylenebilir. Bir başka ifadeyle sosyal medya, bireylerin online olarak sanal bir ortamda buluştukları, birbirleri arasında paylaşım yaptıkları ve fiziken aynı yerde olmasalar dahi başka kişilerle kolaylıkla etkileşim içerisine girebildikleri iletişim ortamına verilen genel addır. Sosyal medya ortamında yapılan paylaşımlar metin, video, fotoğraf ya da ses kaydı gibi çok çeşitli içerikler olabilirler (Çetinöz, 2013, s. 153). 
Kaplan ve Haenlein (2010, s. 60), sosyal medyayı “Web 2.0'ın ideolojik ve teknolojik temellerine dayandırılarak inşa edilen ve kullanıcı merkezli içeriğin yaratımı ile dă̆ıtımına izin veren bir grup internet temelli uygulamalar" şeklinde tanımlamışlardır. Günümüzde bütün insanların iletişim kurma, habere ulaşma, bilgi alma gibi birçok temel gereksiniminin karşılanmasında önemli rol üstlenen sosyal medya ortamlarının ortaya çıkışı, Web 2.0 teknolojilerinin gelişmesi ve ilerlemesiyle birlikte gerçekleşmiştir. 1979 yılında Duke Üniversitesi'nden Tom Truscott ve Jim Ellis'in internet kullanıcısı olan herkesin erişimine olanak tanıyan ve istedikleri biçimde iletiler yayınlamalarına izin veren global bir tartışma sistemi (USENET) geliştirmeleri sonucunda, günümüz sosyal medya ortamlarının temelleri atılmıştır (Akt: Mutlu ve Bazarc1, 2016, s. 30). İlk olarak O'Reilly Medya tarafından 2004'te kullanılan Web 2.0 kavramı, ikinci nesil internet teknolojilerini, herkese açık olan iletişim sitelerini, wikileri ve sanal alemdeki iletişim kanallarını anlatmaktadır. Kısaca Web 2.0 bütün internet kullanıcılarının el birliğiyle yaptıkları paylaşımlar neticesinde ortaya çıkmış olan çok boyutlu sistemi tanımlamaktadır (Vural ve Bat, 2015, s. 3354).

Dijital medya kullanıcılarının tüketici sıfatlarına ek olarak onlara aynı zamanda aktif birer içerik üreticisi sıfatı kazanabilme imkanını da vermektedir. Sosyal medya kullanan bir birey geleneksel medyadaki pasif izleyici profilinden sıyrılıp, istediği takdirde ekranda gördüğü içeriğe katkı verip, katılımda bulunabilmektedir. Yani yeni medya kullanıcısı dilediğinde kendisi bir içerik üreticisi haline gelebilmektedir (Nuran, 2015, s. 39). Kullanıcıların medyadaki içerik üretimi sürecine aktif olarak dâhil olmalarıyla birlikte iletişim literatürü yeni bir kavram kazanmış, yeni medyanın kullanıcıları "Üretüketici" olarak adlandırılmaya başlanmışlardır. Üretüketici kavramı medya içeriklerini tüketirken, aynı zamanda birer içerik üreticileri de olan kullanıcıları tanımlamak için kullanılmıştır.

Özellikle son birkaç yılda globalleşmenin de etkisiyle birlikte medya araçlarına atfedilen güç önemli derecede artmıştır. Bu duruma bağlı olarak insanlar düşüncelerini dünyanın birçok farklı noktasına eskisinden çok daha hızlı, kolay ve ekonomik bir şekilde duyurmaya başlamışlardır. Sosyal medya ile birlikte bireyler bilgiye ve güncel haberlere kolaylıkla ulaşabilir hale gelmiş, dünyanın farklı coğrafyalarındaki kişilere düşüncelerini ileterek, birbirlerini kolaylıkla etkileyebilecek bir statüye ulaşmışlardır. Günümüzde geleneksel medya araçları tekelci olmak ve tek sesli yayıncılık yapmakla eleştirilirken, sosyal medya ortamları bireylere seslerini duyurmak için daha fazla olanak sunduğu için daha çoğulcu ve demokratik olarak değerlendirilmektedir (Tuncer, 2018, s. 10-11). Sosyal medya kavramının hayatımıza getirdiği tüm bu yenilik ve imkanlarla birlikte insanlar arasında artan kullanım sıklığ yeni bir tür bağımlılık tartışmalarını da beraberinde getirmiştir. Son yıllarda "Sosyal Medya/İnternet Bağımlılı̆̆ı" kavramları sosyal bilimlerde sıkça tartışılmaya başlanmış ve birçok çalışmanın ana sorunsalını oluşturmuştur. 


\section{Sosyal Medya Bağımlılığı ve Gençler}

Ortaya çıktıkları günden itibaren popülariteleri her geçen gün daha da artan sosyal medya platformlarından Facebook, Twitter, Instagram, Youtube, Tik Tok ve Netflix gibi sosyal ağlar hem ülkemizde hem de dünyada çok sayıda insan tarafından oldukça yoğun bir biçimde kullanılmaktadır. İnsanlara sanal bir dünya üzerinde birbirlerini takip etme ve iletişim kurma olanakları tanıyan sosyal medya ortamları, son zamanlarda bir iletişim ortamından daha çok gündelik hayatlarımızın olmazsa olmazı formuna bürünmüştür. Akıllı telefon ve internet kullanımı birçok insan için neredeyse yeme içme kadar doğal bir alışkanlık halini almış ve bu yeni teknolojiler her toplumdan, kültürden kalabalık kitleleri geniş bir sosyalleşme paydasında bir araya getirmişlerdir (Çalışkan ve Mencik, 2015, s. 255).

Günlük hayatta her bireyin yoğun olarak kullandığı internet teknolojisi en çok da gençler tarafından kullanılmaktadır. Gençlerde internet kullandıkları zamanın büyük kısmını sosyal medya ortamlarında geçirmektedirler. Günümüzde popüler olarak kullanılan sosyal medya uygulamalarının başında Facebook, Twitter ve Instagram platformları gelmektedir. Bu uygulamalarla birlikte son birkaç yılda dünya genelinde büyük bir hızla kullanıcı sayısı artan "Tik Tok" isimli video paylaşım uygulaması da anılmaya başlanmıştır. Bu uygulamaların bu denli popüler hale gelmelerinin en önemli sebebi insanların zaman ve mekân ayrımı olmaksızın çeşitli sosyal medya uygulamalarını kullanarak birtakım ihtiyaçlarını doyuma ulaştırmaları ve bu araçlar sayesinde motivasyonlarını yükseltmeleridir. Örneğin, Tik Tok uygulaması kullanıcılarına çektikleri videoları düzenleyip, başka kişilerle paylaşma imkânı sağlayarak bireylerin eğlenme ve sosyalleşme ihtiyaçlarını karşılamalarına yardımcı olurken, diğer bir yandan da burada elde edilen popülarite sayesinde maddi olarak da kazanç elde etmelerine aracı olmaktadır.

2020 yılında Tik Tok kullanım alışkanlıklarının incelendiği bir çalışmada İnönü Üniversitesi İletişim Fakültesi öğrencileri ile yapılan görüşmeler sonucunda öğrencilerin Tik Tok'u günlük eğlence ihtiyaçlarını gidermek, farklı kişilerle etkileşime girmek, stres atmak, kendilerini dijital dünyada göstermek gibi çok çeşitli nedenlerle kullandıkları sonucuna ulaşılmıştır (Yetkiner ve Öztürk, 2020, s. 232). Geçen zaman ve yapılan araştırmalar bizlere göstermektedir ki bu mecraların kullanım oranları ve sürelerindeki artış her geçen gün büyümeye devam etmektedir. Sosyal ağların kullanım oranları ve sürelerindeki ciddi artışlar sonucunda "Sosyal Medya Bağımlılı̆̆ı" olgusu yoğun bir şekilde tartışılmaya başlanmıştır.

Sosyal medya bağımlılığı, literatürde konu edinilmiş benzer bağımlılık türleri gibi (oyun bağımlılığı, alışveriş bağımlılığı, alkol bağımlılığı, madde bağımlılığı, internet bağımlılığı) psikolojik bir problem olarak karşımıza çıkmaktadır. Sosyal medyanın bir internet uygulaması olduğu ve sosyal medya ortamlarına erişmek için internet bağlantısına ihtiyaç duyulduğu düşünüldüğünde, "Sosyal Medya ve İnternet Bağımlılı̆̆ı" kavramlarının birbirlerinden ayrı bir şekilde değerlendirilemeyeceği açıktır (Tutgun Ünal, 2015, s. 77). 
Goldberg ilk olarak 1996 yılında kullanmış olduğu internet bağımlılı̆̆ı kavramını DSM-IV'te yer alan madde bağımlılığı ölçütlerinden yola çıkarak şu sözcüklerle tanımlamıştır "On iki aylık bir dönem içinde herhangi bir zaman ortaya çıkan belirtilerden 3'ü veya daha fazlasıyla kendini gösteren, klinik olarak belirgin bir bozulmaya ya da sıkıntıya yol açan uygunsuz internet kullanımı" (Tutgun Ünal, 2015, s. 79). Araştırmalarda, internetin madde bağımlılı̆̆ı gibi vazgeçilemeyen bir davranış bozukluğuna dönüştüğü ve bireylerde zihinsel meşguliyet yarattığına sıklıkla vurgu yapıldı̆̆ görülmektedir.

Yapılan araştırmalar kişilerin evden dışarı çıktıklarında akıllı telefonlarını evde unuttukları zaman tedirgin olduklarını belirlemiş, bireyler bu durumda kendilerini normalden daha güvensiz hissettiklerini söylemişlerdir. Günümüzde insanların aile ve arkadaşlarıyla beraberlerken dahi kendi aralarında sohbet etmekten daha çok akıllı telefonlarıyla vakit geçirdikleri gözlemlenmektedir. Akşam uyumadan önce son yaptığımız şeyin sosyal medya hesaplarımızı kontrol etmek olması ile birlikte sabah yataktan kalkmadan yapılan ilk şey yine sosyal medya hesaplarımızı gözden geçirmek olmaktadır. Sosyal medya bağımlığı gözlenen kişilerde toplantıdayken, okulda ders sırasındayken veya trafikte araç kullanırken telefonlarına bakamama sürelerinin uzaması huzursuzluk yaratabilmektedir (Çiftçi, 2018, s. 418). Bugünlerde insanlar özellikle de gençler diğer kişilerin neler paylaştıklarını görmek, o paylaşımlara yorum yazmak, sanal ortamda üretilen içerikleri beğenmek için deyim yerindeyse can atmaktadırlar. Bu davranış biçimleri de günümüzde yaşanan iletişim problemlerinin başlıca sebeplerini oluşturmaktadır.

Yeni medya teknolojilerinin çok önemli bir konuma sahip olduğu bu dönemde insanlar arası haberleşmeler, etkinliklere katılımlar, toplantılar, çeşitli duyuruların yayımlanması vb. birçok aktivite giderek ăg üzerinden online bir biçimde yürütülmeye başlanmıştır. İnsanların sosyal hayatlarında yaşanan bu dönüşüm ağda olmayan bireyleri de ağın içerisine çekmeye zorlamakta ve sosyal platformlara katılmaya karşı direnç gösteren bireylerin zaman içerisinde toplum tarafından dışlanması gibi sonuçlar doğurabilmektedir. Tüm bu sebeplerden ötürü bireyler yeni iletişim teknolojilerinden uzak duramamakta, aksine gün geçtikçe bu teknolojilere daha da bağımlı hale gelmektedirler.

Sanal bağımlılık ile birlikte birçok duygu, düşünce, anlayış ve alışkanlıklar yok olmaya başlamıştır. Günümüzde dini yöneliş, kitap okuma, sosyal faaliyetler vb. birçok özellikte büyük azalmalar görülürken kronik uyku sendromu, depresyon, anksiyete bozukluğu, intihar, eşcinsellik vb. bozukluk ve rahatsızlıklarda da önemli miktarda artışlar yaşanmaktadır (Atak, 2020, s. 200). Tüm bu problemlerin sonucunda da okumaktan, çalışmaktan vazgeçen, amaçsız ve asosyal bir gençlik kitlesi meydana gelmektedir. Günümüz gençleri okul başarısını, iyi bir kariyer idealini ve evlenmek gibi fikirleri önemsememekle birlikte, otuzlu yaşlarına gelen birçok birey kendi ayakları üzerinde durmak yerine, güvenli hissettiği sınırlar içerisinde kalmayı ve ebeveynleri ile birlikte yaşamayı tercih etmektedirler (Göka, 2020, s. 56-57'den akt. Atak, 2020, s. 203). 
Sosyal medya bağımlılığının günümüz çocuk ve ergenlerine en az uyuşturucu bağımlılığı kadar zararlı olabileceği vurgulanmaktadır. Sanal uzamda kişi zaman algısını kaybetmektedir. Gençlerde akıllı telefon ve sosyal medya kullanımı başladıktan sonra gerçek zaman kavramı manasını yitirmekte, bir başka ifadeyle zaman onlar adına kaybolmaktadır. Gençlerin bu yeni teknolojilere bağımlılıkları arttıkça gerçek hayattan gün geçtikçe uzaklaşmakta, bu durum da onların aile ve sosyal çevreleriyle kurdukları iletişimde ciddi sıkıntılar ortaya çıkarabilmektedir (Büyükgebiz Koca ve Tunca, 2020, s. 79).

Sosyal medya bağımlılığı kavramının daha doğru bir biçimde anlaşılması ve çalışmanın ilerleyen sayfalarında yapılacak olan değerlendirmelere 1şık tutabilmesi adına konuyla ilgili iletişim kuramlarına değinmekte yarar vardır.

\section{Kuramsal Çerçeve}

Bilimin en temelde amacı etrafımızda olup biten olayları, olguları ve durumları anlamımıza yardımcı olmak, belirli bir mantık çerçevesinde bizlere açıklamak, tahmin edilebilir kılmak ve en sonunda kontrol edilebilir hale getirmektir. Bu amaç doğrultusunda yıllar içinde hem fen bilimleri hem de sosyal bilimler alanlarında birçok kuram ortaya çıkmıştır. Bilime hizmet etmek amacıyla geliştirilmiş olan kuramlar gerçeğe ulaşılması, eylemin düzenlenebilmesi ve yeni bilginin üretimine kılavuzluk etmesi açısından son derece önem arz etmektedir. Temelde sosyolojik bir kuram olan pozitivist yaklaşımlara getirilmiş olan eleştiriler ekseninde şekillendirilmiş olan bu kuramlardan biri de iletişim bilimlerinde çok önemli bir yere sahip olan eleştirel kuramdir.

Medya mesajlarının üretildikten sonra tüketim sürecine girmelerinin, ideoloji merkezli çalışmaları "İngiliz Kültürel Çalışmaları" ile başlamıştır. Bu öncü düşüncenin sahiplerinin medya mesajlarına bakış açıları, onların medyaya karşı tutumlarının belirlenmesinde de önemli bir rol oynamıştır. Ekolün hâkim düşüncesine göre, medya toplumdaki baskın düşünce ve değerleri yeniden üreten, şekillendiren bir kurumdur. İngiliz kültürel çalışmaları literatürde "eleştirel çalışmalar" olarak da anılmaktadır. Eleştirel çalışmaların ortak noktası kapitalist ekonomik düzene ve liberal siyasal sisteme yapmış oldukları eleştirilerdir ve bu sebeple eleştirel çalışmalar olarak anılmaktadır (Akbayır ve Dumlu, 2017, s. 7).

19. yüzyılın sonu ve 20. yüzyılın başlarında, sosyalist ve Marksist fikirlerden etkilenen radikal bir kitle toplumu eleştirisi filizlenmekteydi. Bu radikal eleştiri, önceden karşılaşılan eleştirilerin aksine, kitle toplumunda bireylerin hareketsizleştiğini, manipülasyonlara açık hale geldiklerini ve yabancılaştıklarını vurguluyordu (Özçetin, 2019, s. 161). Alana getirilen bu eleştirilerin en dikkat çekici olanları şüphesiz Frankfurt Okulu ve okul içerisinde geliştirilen eleştirel yaklaşımlardı. Eleştirel Sosyal Teori düşüncesinin öncüsü olarak adlandırılan Frankfurt Okulu, “Frankfurt Üniversitesi Sosyal Araştırmalar Enstitüsü” adıyla 1923 yılında Almanya'da kurulmuştur. Okul, eleştirel bakış açısına sahip teori geliştirmeyi ve insanların aklındaki tutarsızlıkları belirleyerek savunucusu oldukları bakış açısını 
yaymak adına yaptıkları çalışmalarla tanınan çeşitli akademisyenlere atıfta bulunmaktadır. Frankfurt okulunun önde gelen temsilcileri olarak Max Horkheimer, Theodor W. Adorno, Jürgen Habermas ve Herbert Marcuse bilinmektedir (Yaylagül, 2006, s. 85).

Eleştirel kuram tahakküm ve sömürünün bir eleştirisidir der Herbert Marcuse (1988, s. 153). "İnsanın sınıflı toplumun üretim sürecinde yönlendirilebilir bir özneden daha fazlası olabileceğini savunur." Horkehiemer'a göre eleştirel kuramın hedefi insanın "kölelikten kurtuluşu” ve "tüm bireylerin mutluluğudur." Eleştirel kuram bir bütün olarak toplumu dönüştürmeyi hedefler ve bunun sonucunda "içerisinde adaletsizlik olmayan bir toplum" ortaya çıkmasını arzular (Akt: Fuchs,2020, s. 40-41). Eleştirel kuramı, Marksist düşünce yapısının temsil edildiği örneklerden birisi olarak tanımlamak mümkündür. Marksizm'in savunduğu düşünce yapısına göre kapitalist toplumlarda bazı toplumsal gruplar ekonomik ve siyasal katılımın dışında tutulmakta, para ve gücü elinde bulunduran kişilerin baskılarıyla sindirilmektedirler (Demirtaş ve Özer, 2015, s. 206).

Frankfurt Okulu'nun temelde ele aldığı kuramsal yaklaşım, kültür endüstrisi kavramı olarak bilinmektedir. Theodor W. Adorno ile Max Horkheimer yaratıcısı oldukları kültür endüstrisi kavramı üzerine 1940'l1 yılların ortasında çalışmaya başlamışlardır. Adorno ve Horkheimer bu kavramla birlikte, kültürel varlıkların endüstriyel olarak yeniden üretilmesini ve ortaya çıkan yeni kültürün nasıl metalaştırıldığını sorgulamışlardır (Mattelart ve Mattelart, 2009'dan akt. Gökbel, 2018, s. 65). Aydınlanmanın Diyalektiği'nin temel temalarından biri olan "bireyin tasfiyesi" Adorno ve Horkheimer'ın kitle kültürü (kültür endüstrisi) analizinin merkezinde yer almaktadır. Burada tekelci kapitalist sistemin tasfiye ettiği bireyler tüketiciye dönüşürken, tüketiciler de araştırma şirketleri tarafından farklı gelir gruplarına göre ayrılarak birer istatistik malzemesi olarak görülmektedirler (Özçetin, 2019, s. 175). Kültür endüstrisi bireylerin duygularına, beğenilerine, arzularına ve bilinç dışı dünyalarına yönelik ürünler üreterek bu ürünleri insanların kullanımına sunmaktadır. Adorno, kültür endüstrisi ortamında üretilen ve toplumun tüketimine sunulan bilgilerle insanların bilgi ve bilinç kalıplarının tam anlamıyla uyuşmadığı fikrini savunmaktadır. Fakat bu durum egemen güçlerin umurunda bile değildir. Kapitalist sistemin yöneticileri için insanların neye ihtiyaçları olduğu ne istedikleri ve ne tarz ürünlerden hoşlanabilecekleri önemsenmezken, neyi daha kolay satın alıp tüketecekleri önem teşkil etmektedir. Kapitalist sistemde üreticinin birinci önceliği üretilen ürünlerle insanların gereksinim ve arzularına cevap vermek değil, bu ürünlerden maksimum düzeyde kazanç elde ederek, kapitalist pazarda büyüyebilmektir (Güngör, 2016, s. 160-161).

Yeni medya teknolojisi ile birlikte taşıdıkları değerin büyük önem kazandığı kitle iletişim araçları, kapitalist düzen için ekonomik, siyasal ve sosyal anlamda büyük önem arz etmektedirler. Dev medya şirketlerinin batılı tekelci patronların elinde bulunması ve elde edilen medya gücünün uluslararası şirketlere hizmet vermesi, yeni iletişim teknolojilerine günümüzde çok büyük önem verilmesine sebep olmaktadır. 
Çünkü bu araçlar, yöneten kesim açısından maddi anlamda büyük gelir kapısıyken aynı zamanda bilinç yönetimi ve ideolojik yönlendirme maksadıyla da sıkça kullanılmaktadır (Yaylagül, 2006, s. 5). Medyanın, toplumda var olan az sayıdaki zengin insanların çıkarları uğruna hizmet ettiğini ve bu doğrultuda sahte bir kamusal alan inşa edildiğine vurgu yapan J. Habermas bu durumu "kamusal alanın yeniden feodalleşmesi" şeklinde tanımlamaktadır. Nihayetinde medya, toplumsal gerçekleri belirli fikir ve amaçlar doğrultusunda şekillendirerek halka iletmektedir. Bu durumu örnekle anlatmak gerekirse; Hollywood filmlerinin Amerikan yaşam kültürünü, Mcdonalds şirketinin de fast-food yemek kültürünü bütün dünyaya gösterip, benimsetmesi medya aracılığıyla gerçekleştirilmiştir (Kurşun, 2017, s. 30-32).

Yeni iletişim teknolojilerinden hareketle günümüz dünyasının ekonomik ve sosyal gidişatı üzerinde düşünenlerden biri de "A $\breve{g}$ Toplumu” (Network Society) kuramıyla alana katkı sağlayan Manuel Castells'tir. Castells'e göre ă̆ toplumunda ekonomi yeniden organize edilmektedir. Yeni kalkınma biçiminde temel dinamik bilgidir. Bilginin üretilmesi, işlenmesi, sembollere dönüştürülerek medyanın kültür endüstrisi ortamında tüketime sunulması gibi bütün süreçler ağ ortamında gerçekleşir. Ağ toplumunda ürün bilgidir, bilgiyi üretenler işçi, kullanılan ă̆ ise iş yeri olarak tanımlanmaktadır. Castells bu ekonominin işçileri sınıfına akıllı telefonlar veya herhangi bir elektronik cihazla ağa erişim sağlayıp içerik üreten herkesi dahil etmiştir. Günümüz ă̆ toplumunda zenginlik ve yoksulluk da ağa erişip erişememek ile ilişkilendirilmektedir. A $\breve{g}$ toplumunda zengin ve seçkin bir birey olarak anılabilmek için dijital medya üzerindeki konumunuzu mümkün olduğunca geniş tutup çeşitlendirmeniz gerekmektedir. Bu yeni dönemde ağ dişında kalanlar yoksullaşmaya ve yalnızlaşmaya mahkumdurlar (Güngör, 2016, s. 169).

Sonuç olarak "Sosyal İkilem" belgesel filmini analiz etmek ve değerlendirmek adına yapılan bu çalışmada Frankfurt okulunun bütün dünyayı etkilediği eleştirel bakış açısı temellerine dayandırılarak hazırlanmıştır. Eleştirel bakış açısına geçmiş dönemlerde geleneksel medya araçları eleştirilirken başvurulduğu gibi, günümüzde yeni medya araçlarını eleştirirken de bu fikirlerden sıklıkla faydalanılmaktadır.

\section{Netflix Platformu ve Tarihçesi}

Web 2.0 teknolojisinin hayatımıza girmesiyle birlikte medya profesyonelleri ve akademisyenler arasında internetin televizyona rakip olduğu tartışmaları dillendirilmekteydi. Ancak teknolojinin hızlı ilerleyişi ve buna paralel olarak Web 3.0 teknolojisinin ortaya çıkması iletişim profesyonelleri arasında yapılan tartışmaların "televizyonun sonumu geliyor" düşüncesine evrilmesine sebep olmuştur. "Televizyon 2.0, Post Televizyon ya da Sosyal TV" olarak adlandırılan yayıncılıktaki bu yeni dönemle birlikte kullanıcılar yeni medya ile etkileşimli, çoklu ortam özelliğine sahip, hipermetinsel, izleyici üretimli içeriklerinde dahil olduğu, sosyal medya ile yöndeşmiş ve büyük bir hızla popülerlik kazanan dijital yayıncılık modelleriyle karşı karşıya kalmışlardır (Dikmen, 2016, s. 124). Günümüzde ise dijital yayıncılık dendiğinde dünya genelinde kullanıcı sayısı ve izlenme oranları da dikkate 
alındıktan sonra herkesin aklına ilk olarak "Netflix" platformunun geleceği su götürmez bir gerçek olarak kabul edilmektedir. Amerika'nın Kaliforniya eyaletinde bulunan Los Gatos şehrinde 1997 yılında ortaya çıkan dijital yayıncılık platformu Netflix, kısa bir süre içerisinde bütün Dünya'da büyük bir ilgiyle karşılanmış ve popüler hale gelmiştir.

1997 yılında Reed Hastings ve Marc Randolph isimli iki arkadaşın akıllarına insanlara posta aracılığıyla DVD kiralama hizmeti verme fikri gelmiştir. 1998 yılına gelindiğinde Hastings ve Randolph tarafından DVD pazarlaması yapmak amaciyla "Netflix.com" alan adıyla bir web sitesi kurulmuştur. Sitenin kurulmasından bir yıl sonra netflix abonelik hizmeti başlatılmış ve site abonelerine aylık belirli bir ücret karşılığında sınırsız DVD kiralama ve izleme hizmeti vermeye başlamıştır. 2000 yılında netflix için devrim olarak adlandırılabilecek kullanıcılarına kişiselleştirilmiş film önerileri sunan yapay zekâ destekli bir sistem kullanılmaya başlanmıştır. Netflix.com 2002 yılına gelindiğinde "NFLX" koduyla, hisse adeti 1 dolar olarak halka arz edilmiştir. 2006 yılında üye sayısı 5 milyona ulaşan netflix, 2008 ve 2010 yılları arasında şirket tarihindeki ikinci büyük devrim olarak nitelendirebilecek bir adım daha atarak "Xbox 360, Ps3, Blu-ray oynatıcılar, Akıllı televizyon kutuları, İnternet bağlantılı televizyonlar ve Akıllı telefonlar" dahil tüm cihazlarda yayın yapabilmek adına bu teknolojileri üreten dev şirketlerle ortaklıklar kurmuştur. 2010 Yılında Netflix ilk kez Amerika dışına açılarak Kanada'da hizmet vermeye başlamıştır. Bu süreçten sonra büyüme hızını ve popülaritesini iyice artırmaya ve tüm dünyada adından söz ettirmeye başlayan netflix platformu, Latin Amerika kıtası ve Karayipler'de de hizmet vermeye başlamıştır. 2011 yılına gelindiğinde yeni üretilen televizyonların kumandalarına özel olarak Netflix tuşu eklendiği görülmüştür. 2012 yılında 25 milyon üye sayısına ulaşmayı başaran dijital platform İngiltere, İrlanda ve Kuzey Ülkelerinde de yayın yapmaya başlamıştır. Platform 2013 yılında " Arrested Development, Hemlock Grove, Orange Is the New Black ve House of Cards " adlarıyla ilk kez kendi yapımları olan dizileri yayımlamıştır. "House of Cards" adlı dizi ile üç "Primetime Emmy" ödülü kazanılmış ve bu ödüller sayesinde internet yayıncılığı alanında tarihte bir ilke imza atılmıştır. 2014 yılında üye sayısı 50 milyon sınırını geçen Netflix hizmeti aynı yıl kullanıcılarına ultra hd kalitesinde $4 \mathrm{~K}$ yayın hizmeti vermeye başlamıştır. 2016 yılında, ülkemiz dahil 130 farklı ülkede daha hizmet vermeye başlayan Netflix toplam 190'1 aşkın ülkedeki abonelerine 21 farklı dilde hizmet sunmaktadır (Netflix-A, 2021). 20 Ekim 2021 tarihinde Netflix tarafından açıklanan rakamlara göre 213,6 milyon aktif aboneye hizmet vermektedirler (Zengin, 2021).

Platformun kendi internet sitesine girildiğinde Netflix kullanıcılarına aşağıdaki cümlelerle tanımlanmaktadır;

"Netflix; internet bağlantıl binlerce cihazda ödüllü diziler, filmler, animeler, belgeseller ve daha fazlasın içeren geniş bir arşiv sunan bir yayın hizmetidir. Tek bir reklam olmadan, istediğiniz kadar, istediğiniz zaman izleyebilirsiniz, hepsi aylık düşük bir ücret 
karşılığında. Her zaman keşfedilecek yeni bir şeyler var, üstelik her hafta yeni diziler ve filmler ekleniyor!" (Netflix-B, 2021).

\section{5. İlgili Çalışmalar}

Literatür incelediğinde sosyal medyayı eleştiren birçok çalışma olmasına rağmen bu çalışmanın üzerine temellendirildiği Netflix yapımı "Sosyal İkilem" belgeseli ile alakalı doğrudan yapılmış bir çalışma bulunmamaktadır. Sosyal medya kavramı ile ilgili alan yazın tarandığında sosyal medya bağımlılığı ile ilgili yapılan çalışmalar ön plana çıkmaktadır. Çalışmanın ana sorunsalını oluşturan sosyal ikilem belgeselinin genelinde de izleyiciye bu tema üzerinden bir anlatım yapıldığı için sosyal medya bağımlılı̆̆ı ile ilgili yapılmış olan bazı çalışmalara değinmekte yarar vardır.

Yazıcı ve Temel (2020) tarafından yapılan bir araştırmada dijital yaşam problemleri ile mücadele boyutunda fazlasıyla önem teşkil eden eğitici içerikli videolar analiz edilmiştir. Çalışmada Youtube' da yayınlanmış olan 10 adet eğitici içerikli kısa film, "Aşırı internet kullanımı, Siber güvenlik, Cinsel istismar, Bilginin doğruluğu/güvenilirliği ve Mahremiyet" alt başlıkları altında içerik analizi yöntemi kullanılarak incelenmiştir. Çalışmadan elde edilen bulgulara bakıldığında, dijital alanda bilhassa aşırı internet kullanımı ve cinsel istismar konularıyla ilgili video içeriklerinin yoğun olarak bulunduğu ve bu tarz içeriklerin izlenme sayılarının da yüksek düzeylere ulaştığı tespit edilmiştir. Ayrıca araştırmada incelenmiş olan eğitici videoların alt yapı ve içeriklerinin profesyonellikten uzak oldukları, dijital problemlerin sadece çocuk merkezli içeriklerle donatıldı̆̆ı ve dijital problemlerin soyut ifadelerle çerçevelendiği sonuçlarına ulaşılmıştır.

Aktan, (2018) yılında Aksaray Üniversitesinde farklı bölümlerde öğrenim gören 315 öğrencinin sosyal medya bağımlılık düzeylerini belirleyebilmek adına yüz yüze anket tekniğini kullanarak yaptığı çalışmasında, beklentilerin aksine öğrencilerin bağımlılık düzeylerinin "az bağımlı" seviyesinde çıktığını tespit etmiştir. Ortaya çıkan sonuçta katılımcıların üniversite seviyesinde eğitim almaları ve belli bir bilinç seviyesine sahip olmalarının etkili olduğu düşünülmektedir. Araştırmada ayrıca sosyal medyada günlük harcanan zamanın artmasına paralel olarak, bireylerin sosyal medya bağımlılık düzeylerinin arttı̆̆ı tespit edilmiştir. Araştırma bulguları göstermektedir ki sosyal medya kullanıcılarının bağımlılık düzeylerinin artmasını önlemek için kullanım sürelerinin kontrol altında tutulması elzemdir. Aktan'a göre (2018, s. 419) çocuk, genç ya da yetişkin kullanıcıların sosyal medyada vakit geçirdikleri süreleri denetim altında tutmak bağımlılığın önüne geçebilmek adına atılacak önemli adımlarından birisidir.

Üniversite öğrencilerinin bağımlılık düzeylerinin ölçüldüğü bir başka çalışma ise Gazi Üniversitesinde eğitim gören 283 öğrenci üzerinde yapılmıştır. Çalışmadan elde edilen bulgulara bakıldığında sosyal medya, katılımcılar tarafından önemli bir sosyalleşme ortamı olarak görülmektedir. Katılımcıların $(\% 74,2)$ 'si gün içerisinde yüz yüze iletişim kurdukları kişilerle dijital ağlar üzerinden yeniden iletişime geçtiklerini belirtmişlerdir. Araştırmada ulaşılan sonuçlardan bir diğeri ise katılımcıların sosyal 
medyada çok fazla vakit geçirdiklerini düşündükleri halde sosyal medya da aktif olma durumundan vazgeçemediklerini belirtmeleridir. Bu durumdan rahatsız olanlar $(\% 47,2)$ 'lik bir oranla neredeyse anketi cevaplayanların yarısını oluşturmaktadır (Hazar,2011, s. 171-173).

\section{Amaç ve Yöntem}

Toplum bilimi olarak tanımlanan iletişim bilimleri, bireylerin ifadeleri anlamlandırabilmesi sürecinde onlara yardımcı olmaktadır. İletişim bilimlerinin içerisinde barındırdığı bir yöntem olan göstergebilim, bir metnin ya da görüntünün görünen anlamının dışında, o metnin altında yatan gerçek anlamının bulunmasını hedefleyen bir araştırma yöntemi olarak karşımıza çıkmaktadır.

Modern manada göstergebilimin temelleri 20. yüzyılın başlarında inşa edilmiştir. Göstergebilimsel analizler bu dönemde Ferdinand Saussure ile C. Sanders Peirce başta olmak üzere, yoğun bir şekilde kullanılmıştır. Saussure (1985, s. 18), literatürde "Semiology" olarak bilinen göstergebilimi "Genel Dilbilim Dersleri" ismiyle yapmış olduğu çalışmasında "Göstergelerin günlük hayatın içerisindeki durumunu inceleyen bir bilim dalı" şeklinde tanımlamıştır. Sanders Pierce, Ferdinand Saussure, Bahtin, Boudrillard, Jakobson, Eco ve Barthes gibi iletişim alanında önde gelen bilim insanlarının verdikleri katkılarla kuramsallaştırılan göstergebilim, açıklama şekilleri bakımından çeşitlilik göstermektedir (Okutan, 2013, s. 14).

Saussure ve Peirce'nin temellerini attığ1 göstergebilimsel analiz yöntemine en büyük katkıyı Fransız bilim insanı "Roland Barthes" yapmıştır. Dil bilimci R. Barthes'in göstergebilim alanında yapmış olduğu çalışmalar, Saussure'in alandaki dil sınırını aşıp, bireylerin günlük hayatlarının bir parçası olan kıyafetler, arabalar, resimler, tablolar, dizi, müzik ve filmler gibi pek çok alanın göstergebilimsel çözümlemeye tabi tutulabilmesine imkân vermiştir. Bu durumu bir örnekle açıklayan Barthes, ekranda karşılaşılan bir film sahnesinde oyuncunun saçından makyajına, yüz hatlarında oluşturulmuş yapay çizgilere kadar karşılaşılan birçok olgunun bir anlamlandırma süreci sonunda meydana geldiğini belirtmektedir. Barthes, bireylere aktarılmak istenen anlamın doğrudan dil kullanılarak değil, çeşitli göstergeler dizgesi aracılığıyla iletildiğini savunmaktadır (Barthes, 2014, s. 65). Çobaner, (2013, s. 220) medya mesajları üzerinde çalışmanın metindeki ileti ve anlamları incelemeyi gerektirdiğinden bahsederken, görüntülerin anlamların karşı tarafa iletilmesinde daha başarılı olduğunu belirtmektedir.

Barthes, göstergebilimin standartlarını yapısal dilbilimden kaynaklanan dört başlığa göre değerlendirmiştir. Bu dört başlık; “Dil ve Söz, Gösteren ve Gösterilen, Dizge ve Dizin, Düz anlam ve Yan anlam" olarak bilinmektedir. Bu başlıklar altında göstergebilim açısından en önemli olanlar "Düz anlam ve Yan anlam” başlıkları olarak öne çıkmaktadır (Akbayır ve Dumlu, 2017, s. 6-7). Anlamlama olarak da bilinen düz anlam ve yan anlam, hedefe verilmek istenen asıl mesaja ve söylenmek istenen asıl söze işaret etmektedir. Barthes, her göstergebilimin bir gösteren ve bir gösterilenle ilişkili olduğuna vurgu yapar. Burada gösterge tek başına bir anlam ifade 
etmemektedir. Anlamlama dediğimiz göstergeye ulaşabilmek, yan anlamı veren gösteren (biçim) ile, gösterilenin (içerik) birleşmesi sonucunda ortaya çıkmaktadır. Kısacası gösteren ile gösterilen bir araya geldikten sonra gösterge ortaya çıkmaktadır (Laloğlu, 2017, s. 109-110).

Göstergebilimsel analiz yöntemi ile hedeflenen; bir yazı veya görüntü içeriğinin açı/görünen anlamının dışında, çözümlenen içeriğin arka planında yatan ve verilmek istenen üstü örtülü mesaja (yan anlam) ulaşabilmektir. Barthes'e göre bir metni anlamlandırılabilmek adına düz anlam ve yan anlam olgularının iyi düzeyde çözümlenmesi gerekmektedir. Anlamlandırma evresinin ilki olarak bilinen, düz anlam (denotation) aşaması göstergenin herkes tarafından görülebilen açık anlamına göndermede bulunmaktadır. (Dağtaş: 2012'den akt. Çobaner, 2013, s. 221). Anlamlandırmanın ikinci aşaması yan anlam (connotation) ise göstergenin seyircinin hislerine, heyecanına ve kültürel değerlerine dolaylı yollardan yapılan göndermeler sonucunda ortaya çıkan derin anlamı yansıtmaktadır. Yan anlam, görüntüsel bir olgu olmasının dışında daha çok kültüre özel olarak anlamlandırılır ve bu aşamada göstergelere pek çok anlam yüklenebilirken her insanın içeriği anlamlandırma düzeyi farklı boyutlarda gerçekleşebilmektedir (Akbayır ve Dumlu, 2017, s. 7).

$\mathrm{Bu}$ çalışmanın da en temelde amacı yukarıda detaylarıyla birlikte açıklanan göstergebilimsel analiz yönteminden faydalanarak Netflix dijital platformunda yayımlanan "Sosyal İkilem" (Social Dilemma) isimli belgesel filminin alt metinlerini görünür hale getirebilmektir. Çalışmada, Barthes'in göstergebilimsel yöntem literatürüne kazandırdığı kavramlar olan "düz anlam ve yan anlam" olguları çerçevesinde değerlendirmeler yapılacaktır. 


\section{Bulgular ve Yorum}

Tablo 1. Belgesel Başlangıç Sahnelerinin Göstergebilimsel Analizi.

\begin{tabular}{|l|l|l|}
\hline \multirow{2}{*}{\multicolumn{1}{|c|}{ Gösterge }} & \multicolumn{2}{c|}{ Gösterilenler } \\
\cline { 2 - 3 } & \multicolumn{1}{|c|}{ Düz Anlam } & \multicolumn{1}{c|}{ Yan Anlam } \\
\hline $\begin{array}{l}\text { Konuşmacılar, Sade ortam, } \\
\text { Koltuk, Sandalye, Akıllı Telefon. }\end{array}$ & $\begin{array}{l}\text { Röportaj için hazırlanan } \\
\text { konuşmacılar. }\end{array}$ & $\begin{array}{l}\text { Tedirgin, endişeli ruh } \\
\text { hali. Telefon bağımlılığı. }\end{array}$ \\
\hline
\end{tabular}

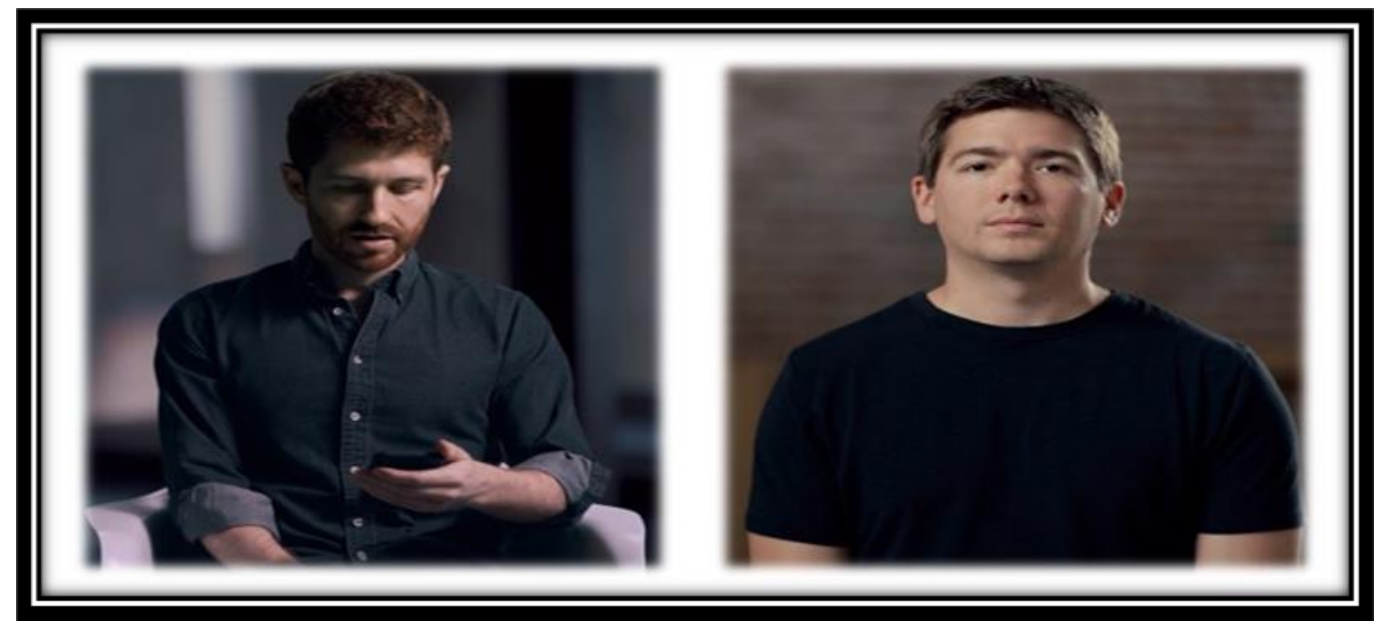

Görsel 1-2

Belgeselin başlamasıyla birlikte popüler sosyal medya sitelerinin üst kademeleri ve karar mercilerinde yönetici pozisyonlarında çalışmış kişilerin yapılacak olan çekimlere hazırlık aşamalarına tanıklık ediyoruz. Buradaki görüntülerde izleyici çekim için hazırlık yapan konuşmacıları görmektedir. Görüntü içerdiği yananlam bakımından değerlendirildiğinde ise konuşmacıların tek bir koltuk/sandalyeden başka bir eşyanın olmadığı bu görüntüyle izleyiciye sorgu odalarını anımsatan boş bir oda da çekimlerinin yapılması ve daha belgeselin başında yüzleri ile davranışlarına yansıyan huzursuzluk, tedirginlik ve endişeli olma halleridir. Bu durum bireylerin yaşadıkları iletişim kaygısını belirgin hale getirmektedir. Çakmak (2018, s. 36) iletişim kaygısını, kişinin bir başka kişi veya kişilerle iletişim halindeyken hissettiği endişe, korku ve gerginlik hali olarak tanımlamaktadır. Bireylerin, iletişim halinde duydukları kaygı onların tavır ve davranışlarına yansımaktadır. Bunun sonucunda da kişinin o anda çektiği sıkıntı belirgin hale gelmektedir ve bu durum da yaşanılan iletişim kaygısı durumunu ortaya çıkarmaktadır. Son olarak sol taraftaki görselde (Sahne-1) gösterilen konuşmacının belgeselin tamamı boyunca eleştirmekte olduğu akıllı telefon bağımlılı̆̆ından aslında kendisinin de muzdarip olduğunu izleyiciye hissettiren kare ise yönetmenin izleyiciye vermek istediği bir başka yan anlam içeren mesaj olarak karşımıza çıkmaktadır. 
Tablo 2. Aile İçi İletişim Problemlerine Örnek Teşkil Eden Sahnelerin Göstergebilimsel Analizi.

\begin{tabular}{|l|l|l|l|}
\hline \multicolumn{2}{|c|}{} & \multicolumn{2}{c|}{ Gösterilenler } \\
\cline { 3 - 4 } & Gösterge & Düz Anlam & Yan Anlam \\
\hline Sahne 3. & Baba ve oğul. & $\begin{array}{l}\text { Bir masa etrafında } \\
\text { oturan baba ile oğul. }\end{array}$ & $\begin{array}{l}\text { Aile içi iletişim problemi } \\
\text { ve telefon bağımlılığı. }\end{array}$ \\
\hline Sahne 4. & Anne ve kız. & $\begin{array}{l}\text { Akşam yemeği } \\
\text { hazırlığı. }\end{array}$ & $\begin{array}{l}\text { Aile içi iletişim problemi } \\
\text { ve telefon bağımlılı̆̆ı. }\end{array}$ \\
\hline
\end{tabular}

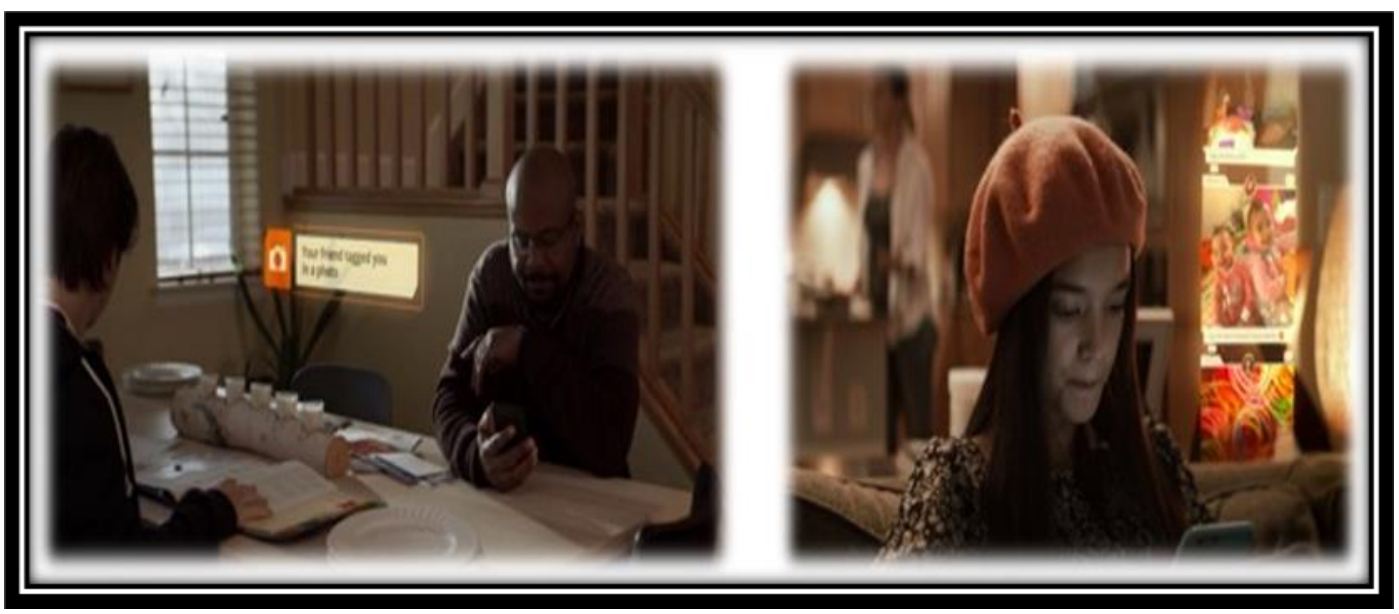

Görsel 3-4

Sahne-3'te izleyiciler baba ve oğulun evin salonunda bir araya geldikleri kısa bir görüntüyle karşılaşmaktadırlar. Görüntü yan anlam bakımından incelendiğinde, baba ile oğul arasında hiçbir sözlü iletişimin gerçekleşmediği görülmektedir. Görüntüde baba oğlunun salona geldiğini fark ettiği halde ona hiçbir şey söylemeden akıllı telefonuyla ilgilenmeye devam ederken, erkek karakterde babası ile iletişim kurmayı tercih etmeden direkt olarak ödevleriyle ilgilendiği bir sahneye tanıklık etmekteyiz. Sahne-4 incelendiğinde ise düz anlam olarak izleyiciye akşam yemeği hazırlı̆̆ında olan ve kızından kendisine yardım etmesini isteyen anne ile kendisinden yardım istenilen evin küçük kızı gösterilmektedir. Sahne yan anlam bakımından incelendiğinde akıllı telefonundan kafasını kaldırmayan ve annesini duymazdan gelen ergen bireyin akıllı telefon/sosyal medya bağımlılık düzeyi izleyiciye yansıtılmaktadır. Bu görüntülerden hareketle yeni medya araçlarının hayatımıza girmesiyle birlikte önemli bir tartışma konusu haline gelen kişilerarası iletişimin ve aile içi ilişkilerin zayıfladığı, insanların bu yeni dönemde daha içe kapanık kişiliklere büründükleri tartışmaları akıllara gelmekte ve desteklenmektedir. 
Tablo 3. Gençlerde İletişim Kurma Problemi ve Telefon Bağımlılı̆̆ına Örnek Teşkil Eden Sahnelerin Göstergebilimsel Analizi.

\begin{tabular}{|l|l|l|l|}
\hline \multirow{2}{*}{\multicolumn{2}{|c|}{ Gösterge }} & \multicolumn{2}{c|}{ Gösterilenler } \\
\cline { 3 - 4 } & $\begin{array}{l}\text { Güzç erkek karakter } \\
\text { ve arkadaşı. }\end{array}$ & $\begin{array}{l}\text { Kafede oturan iki } \\
\text { arkadaş. }\end{array}$ & $\begin{array}{l}\text { Kişilerarası iletişimsizlik } \\
\text { ve telefon bağımlılı̆̆ı. }\end{array}$ \\
\hline Sahne 5. & Genç erkek karakter. & $\begin{array}{l}\text { Sosyal medyada } \\
\text { gezinen genç birey. }\end{array}$ & $\begin{array}{l}\text { İçe dönük birey ve akıllı } \\
\text { telefon dolayımlı } \\
\text { sosyalleşme. }\end{array}$ \\
\hline Sahne 6. & Genç erkek karakter. & Ders dinleyen öğrenci. & Telefon bağımlılı̆̆1. \\
\hline Sahne 7. & & & \\
\hline
\end{tabular}

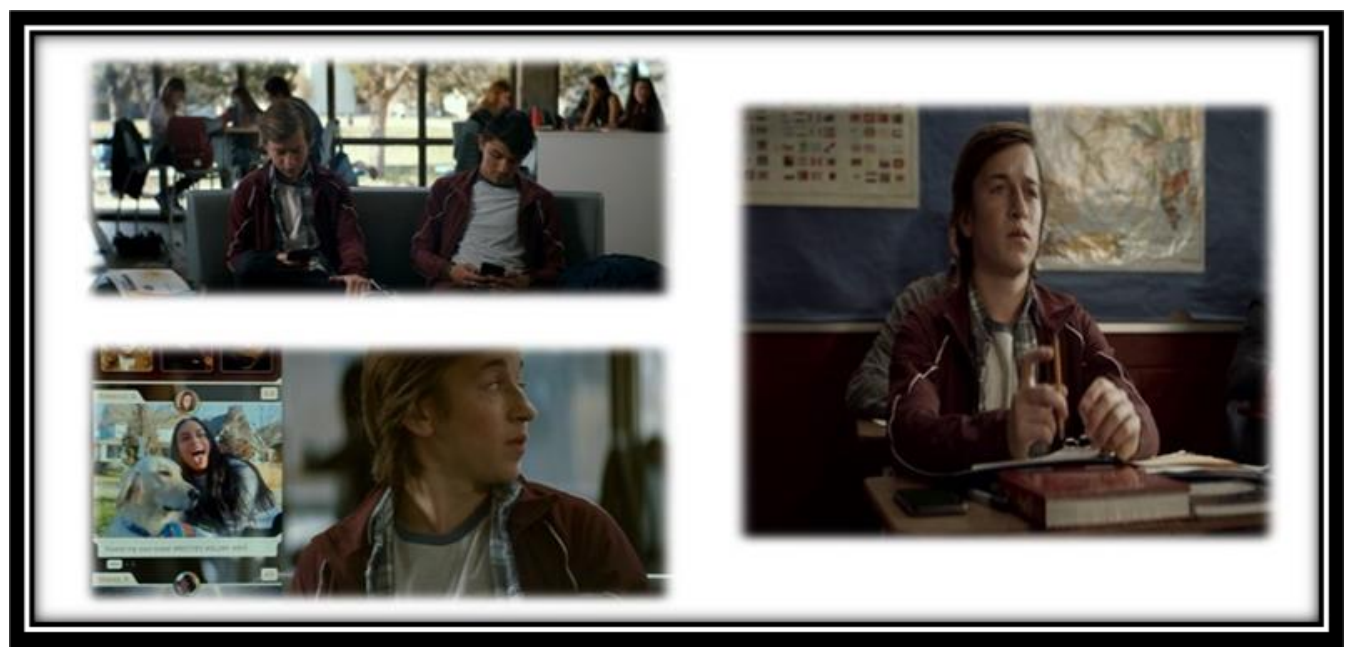

Görsel 5-6-7

Bu bölümde ele alınan sahnelerden Sahne-5 incelendiğinde, bir kafede oturan iki genç arkadaşın birbirleriyle iletişim kurmak yerine ikisinin de akıllı telefonlarıyla ilgilendikleri görülmektedir. Sahne-6 incelendiğinde genç erkek karakterin yine aynı kafede hemen arka masalarında oturan kız arkadaşı ile yüz yüze iletişim kurmak yerine sosyal medya aracılı iletişimi tercih ettiği görülmektedir. Sahne-7 incelendiğinde ise düz anlam olarak okulda ders dinleyen bir öğrenci görülmekteyken, görüntü yan anlam bağlamında değerlendirildiğinde sıranın üzerindeki akıllı telefon göze çarpmakta ve bu durumun öğrencinin derse olan ilgisini ve dikkatini fazlasıyla dağıttığı görülebilmektedir. Günümüz gençlerinin birçoğunda gözlemlenen sanal uzamda iletişim kurma ve arkadaşlık edinme alışkanlıkları bireylerin fiziksel dünyada gün geçtikçe daha az bir araya gelmelerine neden olmaktadır. Gençler fiziksel olarak bir araya gelseler dahi ortamdaki varlıklarını unutarak yine akıllı cihazları aracılığıyla dijital dünyada iletişim kurmayı tercih etmekte ve deyim yerindeyse o cihazların içinde yaratılan sanal dünyaya hapsolmaktadırlar. Tüm bu davranış pratikleri yeni neslin fiziksel ortamlara 
katılımını giderek daha da zayıflatmakta birlikte, onlar için odalarına kapanma, bireyselleşme ve zamanla yalnızlaşma gibi çeşitli psikolojik problemler yaşamalarına sebep olmaktadir.

Tablo 4. Benlik Sunumu Kavramı ve Kullanımlar Doyumlar Teorisine Örnek Teşkil Eden Sahnelerin Göstergebilimsel Analizi.

\begin{tabular}{|l|l|l|l|}
\hline \multicolumn{2}{|c|}{} & \multicolumn{2}{c|}{ Gösterilenler } \\
\cline { 2 - 4 } & G̈̈sterge & Düz Anlam & Yan Anlam \\
\hline Sahne 8. & $\begin{array}{l}\text { Akıllı telefon } \\
\text { ve fotoğraf. }\end{array}$ & $\begin{array}{l}\text { Yatakta telefonuyla oynayan } \\
\text { kız. }\end{array}$ & $\begin{array}{l}\text { Filtre programı kullanımı ve } \\
\text { idealize edilmiş görüntü. }\end{array}$ \\
\hline Sahne 9. & $\begin{array}{l}\text { Kız çocuk } \\
\text { karakter. }\end{array}$ & $\begin{array}{l}\text { Sosyal medyada profiline gelen } \\
\text { yorumları inceleyen kız çocuk. }\end{array}$ & $\begin{array}{l}\text { Hedeflenen doyuma } \\
\text { ulaşmanın verdiği mutluluk. }\end{array}$ \\
\hline Sahne 10. & $\begin{array}{l}\text { Kız çocuk } \\
\text { karakter. }\end{array}$ & $\begin{array}{l}\text { Sosyal medyada profiline gelen } \\
\text { yorumları inceleyen kız çocuk. }\end{array}$ & $\begin{array}{l}\text { Olumsuz yorum karşısında } \\
\text { yaşanılan mutsuzluk ve } \\
\text { huzursuzluk. }\end{array}$ \\
\hline Sahne 11. & $\begin{array}{l}\text { K1z çocuk } \\
\text { karakter. }\end{array}$ & $\begin{array}{l}\text { Ayna karşısında ağlayan kız } \\
\text { çocuk. }\end{array}$ & $\begin{array}{l}\text { Psikolojik çöküntü, bunalım } \\
\text { ve içe kapanma. }\end{array}$ \\
\hline
\end{tabular}

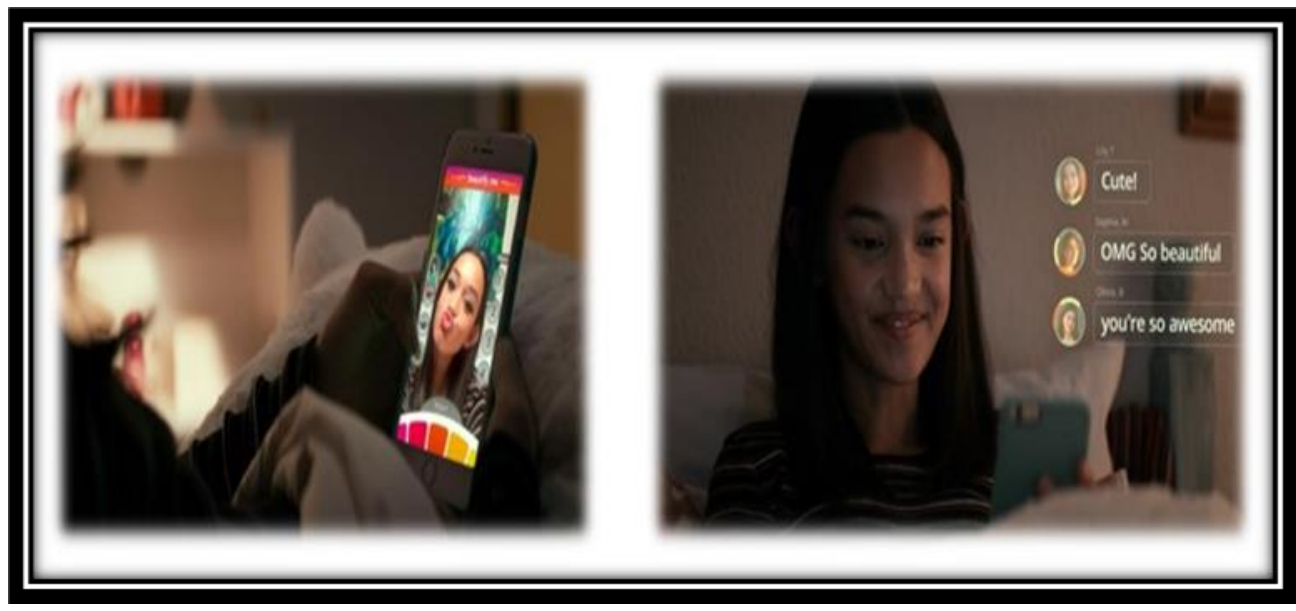

Görsel 8-9

Kişilerarası iletişimde bireyler toplumdaki diğer insanlar tarafından beğenilip, kabul görebilmek adına farklı sunum şekilleri belirlemektedir. Bu durum kişinin toplumda başkaları tarafından nasıl algılanmak istediğiyle ilişkilidir. Erving Goffman'ın literatüre kazandırdığı benlik sunumu kavramı insanların kendi kendilerini sunum biçimleri üzerine yoğunlaşır. Goffman çalışmasında insanların kendilerini ifade etmek amacıyla çok çeşitli teknikler geliştirdiklerinden bahsetmektedir. Çünkü insan yaratılışı gereği başkaları tarafından sevilmek ve beğenilmek istemektedir. Goffman kuramında insanları kendi yaşamlarının aktörleri ya da oyuncuları olarak tanımlamaktadır (Güngör, 2016, s. 338-342). Goffman'ın söylediği gibi karşı tarafta 
izlenim oluşturma ve bununla birlikte gerçekleşen sosyal benliği yaratma süreci sosyal hayatımızın en önemli zamanlarından biri haline gelmektedir. Gerçek olan ile sahte olan arasındaki farkın gün geçtikçe kaybolduğu, hatta ayırt edilemez hale geldiği günümüz toplumunda insanlar ağ üzerinden kendilerine sanal kimlikler oluşturarak gerçek kimliklerini gizleyebilmekte, kafalarında kurup idealize ettikleri benliklerini ise sanal alemde kullanabilmektedirler. Bilhassa günümüz gençliğinin sosyal medya ortamlarında kendilerini daha özgür hissederek gerçek yaşamda ulaşamadıkları kişilik ve başarı profillerini sosyal medya ortamlarında sergileme eğiliminde olduklarıyla sıkça rastlanmaktadır (Kavut, 2018, s. 6).

Sahne-8 incelendiğinde ergenlik çağında olan küçük kız karakterin yatağında akıllı telefonuyla ilgilendiğini ve hayalinde idealize ettiği görünüme kavuşmak adına günümüzde sıklıkla başvurulan fotoğraf filtreleme (düzenleme) programlarından faydalandığ 1 görülmektedir. Sahne-9 incelendiğinde ise kız karakterin çeşitli filtreler uyguladıktan sonra sosyal medya hesabında paylaştığı fotoğrafa gelen güzel yorumlara verdiği tebessüm ve bu yorumlardan dolayı ortaya çıan mutluluk hali izleyiciye gösterilmektedir. Çetin'e göre (2015, s. 786) sosyal medya kullanıcıları dijital platformlarda ürettikleri içeriklerle sosyal bir kişilik profiline bürünürlerken diğer bir yandan da paylaştıkları içeriklerin beğenilmesini ve bu içeriklere diğer kullanıcılar tarafından yorum yapılmasını beklemektedirler. Yaratılan bu dijital dünyada yalnızca "gösterme ve görünme" amaç edinilmiş ve bu minvalde bir ortam tasarlanmıştır. Günümüzde sosyal medya araçlarını kullanan birçok kişinin özellikle de gençlerin, kendilerini etraflarındaki insanlara sürekli olarak anlatmak, tanıtmak ve beğendirmek zorundaymış gibi hissettikleri görülmekte, paylaşımlarına gelen beğeni, yorum sayılarına göre de belirli bir doyuma ulaştıkları gözlemlenmektedir.

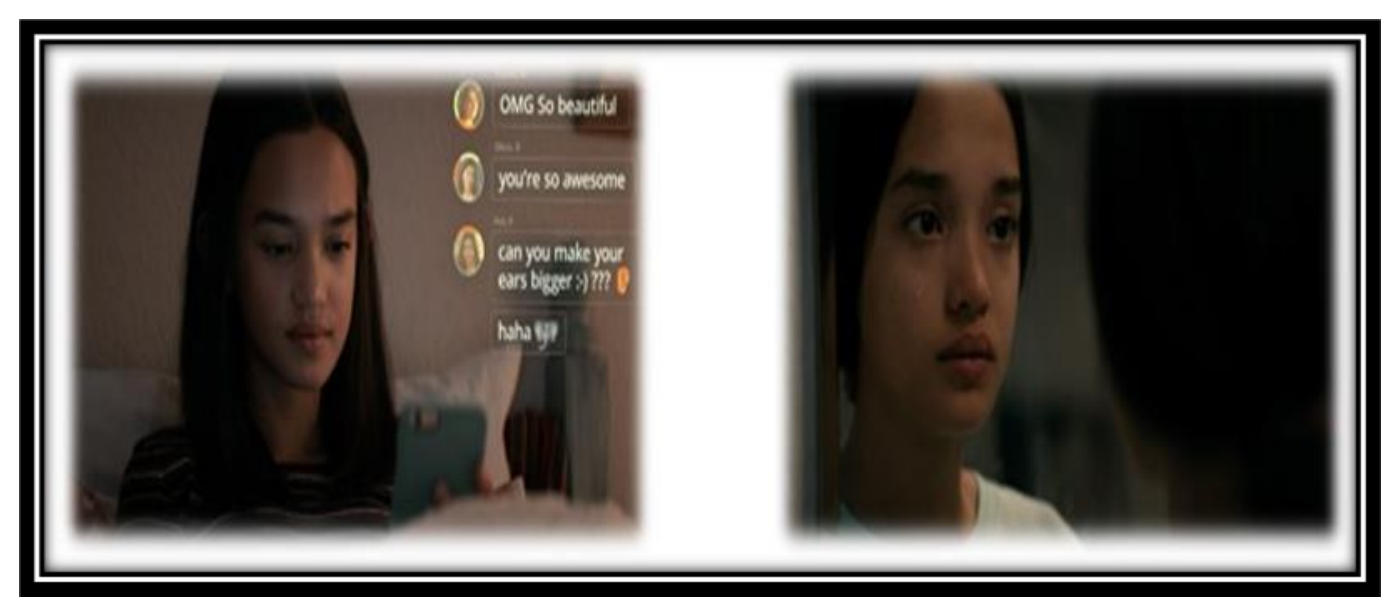

Görsel 10-11

Günümüzde iletişimin ana karakteristik özelliklerinden biri aracılanmış niteliğidir. Medya kullanım alışkanlıklarıyla ilgili olarak iletişim çalışmalarına baktığımızda 1970'li yıllarda Blummer ve Katz tarafından ortaya konulan “Kullanımlar ve Doyumlar" teorisi üzerinden bir değerlendirme yapılabilir. Türk'e göre (2017, s. 2) kullanımlar ve doyumlar yaklaşımı bireylerin medyayı bilişsel, duygusal ve sosyal anlamda tatmin elde etmek için kullandıkları görüşü üzerine temellendirilmiştir. Bu 
bağlamda kullanıcı çevreyle, arkadaşlarıyla ya da dünya ile ilgili bilgi ihtiyacını karşılamak için medyayı kullanarak bilgisel tatmin elde eder. Bireyler aynı zamanda sevgi, saygı, takdir görme gibi içsel motivasyon unsurlarını tatmin etmek için yani duygusal tatmini sağlamak amacıyla da medyayı yoğun olarak kullanmaktadırlar.

Yukarıdaki görselde paylaşılan Sahne-10 incelendiğinde, ergenlik çağındaki kız çocuk karakterin sosyal medya üzerinden paylaştı̆̆ fotoğrafa gelen olumsuz bir yorum sonrasında yüzünde şekillenen mutsuzluk ve huzursuzluk ifadesi izleyiciye yansitılmaktadır. Sahne-11'de ise ayna karşısında kendisini izleyen kız karakterin sosyal medya üzerinden gelen eleştiri sonrasında yaşadığı psikolojik bunalım ve sonrasında gözlerinden süzülen yaş dikkat çekmektedir. Sosyal medya ortamlarını herkes gibi belirli bir doyum elde etmek için kullanan bireyin olumsuz bir paylaşım ve yorumla karşılaştığında yaşayacağı içsel bunalıma örnek teşkil eden bu sahne, günümüzde çoğu genç bireyin kendi içinde yaşamış olduğu benzer problemlere işık tutmaktadir.

Tablo 5. Gerbner'in Ekme Kuramı ve Goffman'ın Çerçeveleme Kuramına Örnek Teşkil Eden Sahnelerin Göstergebilimsel Analizi.

\begin{tabular}{|l|l|l|l|}
\hline \multirow{2}{*}{\multicolumn{2}{|c|}{ Gösterge }} & \multicolumn{2}{c|}{ Gösterilenler } \\
\cline { 3 - 4 } & Düz Anlam & Yan Anlam \\
\hline $\begin{array}{l}\text { Sahne } \\
12 .\end{array}$ & $\begin{array}{l}\text { Genç erkek } \\
\text { karakter ve video } \\
\text { görselleri. }\end{array}$ & $\begin{array}{l}\text { Akıllı telefonu aracıllı̆ıyla } \\
\text { video içerikleri izleyen genç } \\
\text { birey. }\end{array}$ & $\begin{array}{l}\text { Yeni fikir oluşumu ve } \\
\text { etkilenme süreci. }\end{array}$ \\
\hline $\begin{array}{l}\text { Sahne } \\
13 .\end{array}$ & $\begin{array}{l}\text { Genç erkek } \\
\text { karakter ve video } \\
\text { görselleri. }\end{array}$ & $\begin{array}{l}\text { Akıllı telefonu aracıllğılyla } \\
\text { video içerikleri izleyen genç } \\
\text { birey. }\end{array}$ & $\begin{array}{l}\text { Yeni fikir oluşumu ve } \\
\text { etkilenme süreci. }\end{array}$ \\
\hline $\begin{array}{l}\text { Sahne } \\
14 .\end{array}$ & $\begin{array}{l}\text { Genç erkek } \\
\text { karakter ve siyasi } \\
\text { eylemciler. }\end{array}$ & $\begin{array}{l}\text { Protestocuların arasında } \\
\text { gezinen genç birey. }\end{array}$ & $\begin{array}{l}\text { Medyadan etkilenme ve } \\
\text { eyleme geçme. }\end{array}$ \\
\hline $\begin{array}{l}\text { Sahne } \\
15 .\end{array}$ & $\begin{array}{l}\text { Genç erkek } \\
\text { karakter ve siyasi } \\
\text { eylemciler. }\end{array}$ & $\begin{array}{l}\text { Gösteriler sırasinda } \\
\text { tutuklanan genç erkek. }\end{array}$ & $\begin{array}{l}\text { Tedirginlik, pişmanlık ve } \\
\text { huzursuzluk hali. }\end{array}$ \\
\hline
\end{tabular}




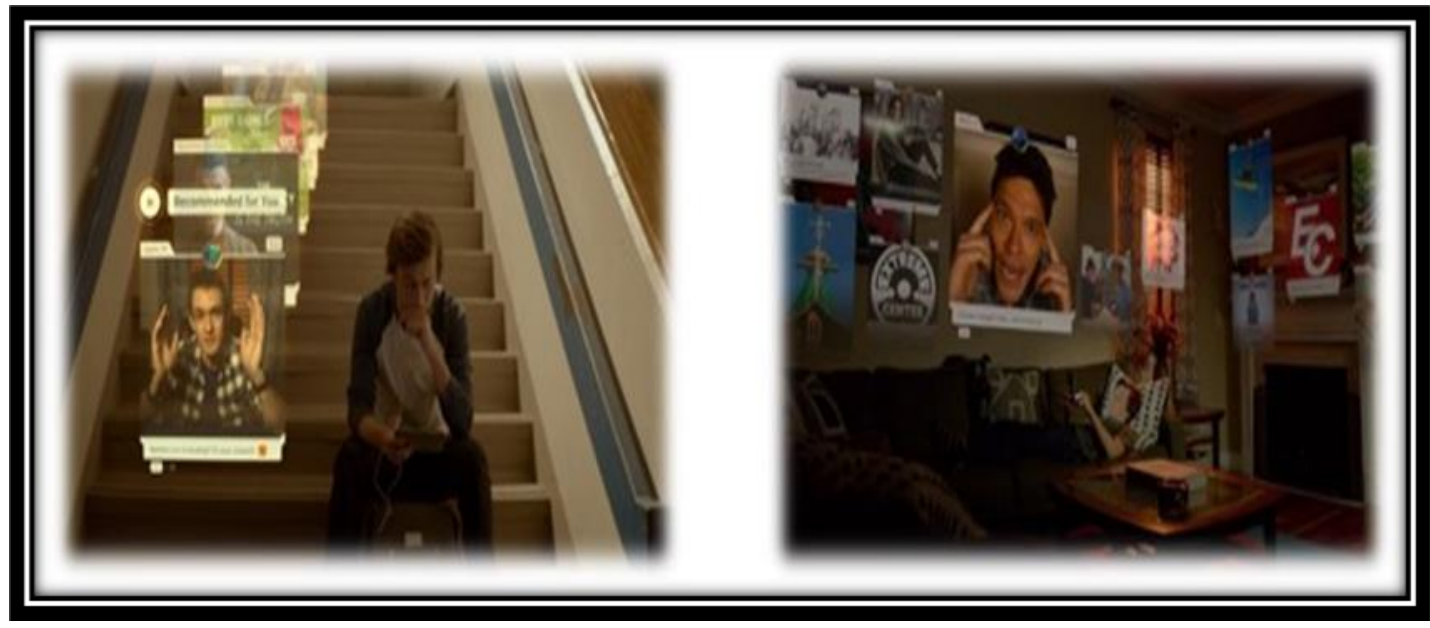

Görsel 12-13

İletişim kuram ve yaklaşımları incelendiğinde en ilgi gören kuramlardan birisi de George Gerbner tarafından "1969" yılında geliştirilen "Ekme Kuramı" (Cultivation Theory) olmuştur. Geliştirildiği zamandan günümüze kadar televizyonun etkilerini değerlendirmek amacıyla sıkça başvurulan bu kuramdan, günümüz yeni medya araçlarının etkilerini araştırıp, değerlendirirken de sıkça faydalanılmaktadır. Güngör'e göre (2016, s. 114) bu kuramın temelinde televizyonun inançları, düşünceleri etkilemede ve davranış biçimleri oluşturmada büyük güce sahip olduğu görüşü yatmaktadır. Gerbner, televizyondan sunulan iletilerin insanlar üzerinde hemen etki yapmadığından bahsetmektedir. Bu süreçte izleyiciye çok çeşitli formatlarda (haber, drama, müzik, eğlence...) vb. verilen iletiler zamanla onların inançları, düşünceleri, değerleri içerisine sızarak tutumlarını, davranışlarını ve tavır alış biçimlerinin üzerinde etkisini göstermekte ve şekillendirmektedir.

Medya tarafından maruz kalınan içeriklerin etkilerinin incelendiği kuramlardan bir diğeri ise ilk kez Goffman tarafından kullanılan "Çerçeveleme Kuramı" olarak bilinmektedir. Çerçeveleme teorisinden, birçok farklı alanda algı ve kanaat oluşturma bağlamında yararlanılmaktadır. Teori iletişim çalışmalarında ise sıklıkla medya araştırmalarında kullanılan, medyanın gündem yaratma işlevine odaklanan bir kavram olarak karşımıza çıkmaktadır (Savaş, 2015, s. 158). Baskın ideolojinin taşıyıcısı görevi gören çerçeveler, toplumların günlük yaşamlarında önemli yeri olan haber metinlerinin anlamlandırılması ve toplumsal gerçekliğin kurgulanmasında büyük rol oynamaktadırlar. Toplumsal süreçler içerisinde toplumun benimsediği egemen söylemler tarafından belirlenen çerçeveler, haber metinlerinin üretim sürecinde de kullanılmaktadır. Bir çeşit kategorizasyon da denebilecek bu çerçevelerin, alımlayıcı toplulukların kendi çerçeveleri ile etkileşime girmesiyle gelişen süreçte de toplumsal gerçeklik inşa edilmektedir (Küçük Durur, 2011, s. 29). Çerçevelemenin sonuçları bireysel ve toplumsal düzeyde anlaşılabilmektedir. Bireysel düzeydeki sonuç, belirli çerçevelere maruz kalmaya bağlı olarak bir konu ile ilgili tutumların değişmesi olabilmektedir. Toplumsal düzeyde ise çerçeveler, siyasal toplumsallaşma, karar 
verme ve toplu eylemler gibi sosyal düzeydeki süreçlerin şekillenmesine katkıda bulunabilmektedir (Erdoğan, 2014, s. 37).

Sahne-12 ve Sahne-13 incelendiğinde fikir ve görüşlerinin manipüle edilmeye ve şekillendirilmeye açık, çevresinde olan bitenlerden etkilenme oranlarının olgunluk dönemine oranla daha yüksek seviyelerde olduğu bir yaşta olan (ergenlik çağı) genç erkek bireyin, akıllı telefonu aracılığıyla kullandı̆̆ı sosyal medya uygulamaları üzerinden yoğun bir biçimde siyasal içerikli paylaşım ve mesajlarla karşılaştı̆̆ı izleyiciye gösterilmektedir. İlerleyen süreçte çocuğun karşısına çıkan siyasal içeriklere ilgi duymaya başladığı görülmekte ve izleyiciler çerçeveleme kuramıyla anlatılmak istenen medyanın belirli bir konuda insanların tutum ve davranışlarını şekillendirebileceği yönündeki görüşün gerçek hayatta yansımasına şahitlik etmektedirler.

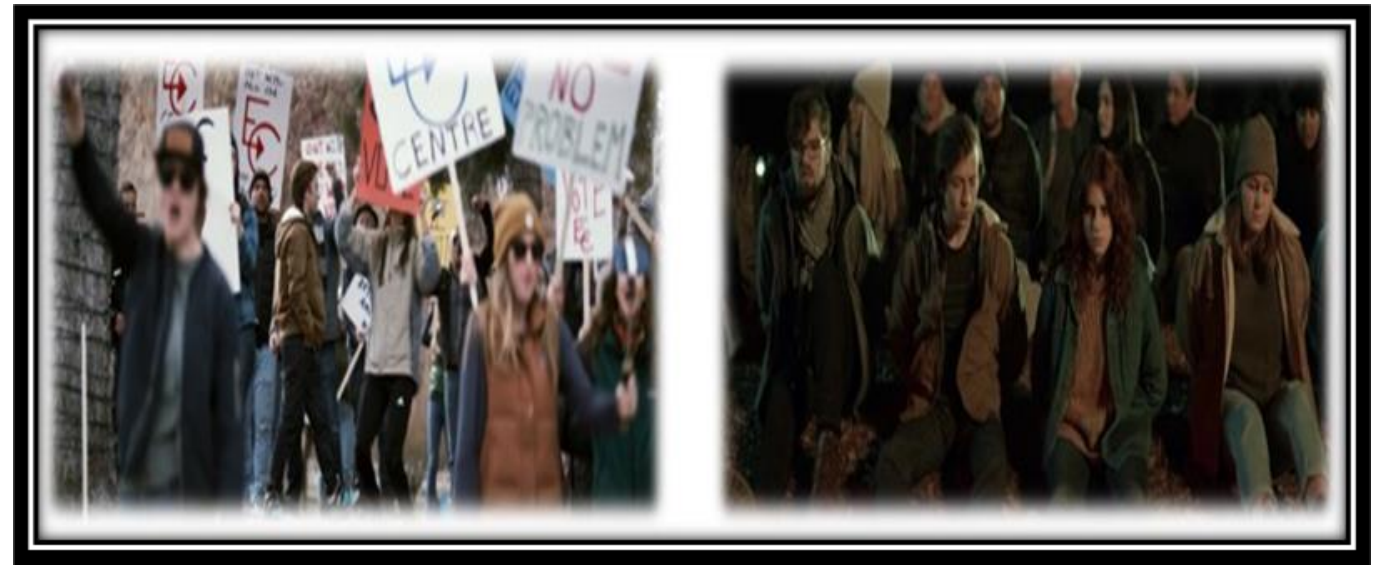

Görsel 14-15

Sahne-14'te ise sürekli maruz kaldığı siyasal içerikler ve fikirlerden zamanla etkilenen genç karakterin sokakta yapılan siyasal bir eyleme katıldığ görüntüyle birlikte Gerbner'in ekme kuramında belirttiği kitle iletişim araçlarının insanların düşüncelerini istenilen doğrultuda yavaş yavaş ve zamanla şekillendirdiği görüşü desteklenmektedir.

Sahne-15'te ise o ortamda neden ve ne şekilde bulunduğunu dahi tam olarak idrak edemediği protestonun sonucunda diğer eylemcilerle birlikte tutuklanan erkek çocuk karakterin tedirgin ve pişman görüntüsü izleyiciye resmen bir uyarı nitelendiğinde yansitılmaktadir.

\section{Sonuç ve Öneriler}

Yeni iletişim teknolojileri hayatımızda gerçek dünyanın yanında sanal bir dünya kurgulamamıza olanak sağlamıştır. Bir yandan insanların fitratında olan merak duygusu, çevrelerinde olan bitenlerden haberdar olma istekleri, diğer yandan ise popüler kültürle birlikte daha da ön plana çıkan başka kimseler tarafından beğenilme, ilgi görme arzusu yeni medya teknolojilerinin hayatımızda yer edinmesiyle birlikte hat safhaya ulaşmıştır. Son yıllarda bütün insanlığın en popüler olgularından biri haline gelen sosyal medya ortamları, bünyesinde barındırdığı sayısız içerik ve 
kullanıcılarına sunduğu çok yönlü iletişim pratikleri sayesinde günlük yaşantımızın ayrılmaz bir parçası haline gelmiştir. Yeni medya teknolojilerinin önlenemez yükselişi her geçen gün büyük bir hızla devam etmekte ve gelişmekteyken, insanların da bu teknolojilere olan bağımlılık düzeylerinin aynı oran ve hızla arttığı gözlemlenmektedir.

Frankfurt okulunun önde gelen düşünürlerinden birisi olan Max Horkheimer, "Insanın eşya üzerinde iktidar kurma isteği ne kadar yoğun olursa, eşyanın onun üzerindeki tahakkümü de o kadar ă̆ır olur ve insan da gerçek bireysel özelliklerinden o kadar uzaklaşır, zihni giderek bir biçimsel akıl otomatına dönüşür" sözleri ile günümüzde yaşanan problemlere önemli düzeyde 1şık tutmaktadır (Özçetin, 2019, s. 171). İncelenen belgesel filmle birlikte hayatımıza getirdiği problemlerin bir kez daha farkına varılıp sorgulandığı akıllı telefon ve internet bağımlılı̆̆ı, teknolojinin bireyler üzerindeki tahakkümünü gözler önüne sermektedir. Günümüzde önlenemez bir hıla üretilen ve tüketilen tüm bu teknolojiler, bireyleri ve özellikle de genç nesilleri sosyalleşmekten alıkoymakta, yalnızlaştırmakta ve içe kapanık bireyler haline dönüştürmektedir.

Çalışmanın üzerine temellendirildiği "Sosyal İkilem" belgesel filminde izleyiciye verilmek istenen en temel mesaj, üretilen tüm bu yeni teknolojilerin bilinçli kullanılmadıkları takdirde bireyler açısından ortaya çıkarabilecekleri büyük problemleri izleyiciye aktarabilmektir. Kişinin ilgisini çekmeye yönelik geliştirilen algoritma ve yazılımlar sayesinde dijital dünyanın içerisinde kaybolan bireylerin yine bu dünyada yollarını bulabilmeleri adına yeni medya ortamlarını ve dijital ağları ne şekilde doğru kullanacakları, bu teknolojilerden nasıl faydalanmaları gerektikleri konusunda bilinçlendirilmeleri son derece önem teşkil etmektedir. Tüm bu bilgiler 1şığında okullarda yeni medya, akıllı telefon bağımlılığı, teknoloji ve internet bağımlılığı, sanal uzamda kendini korumak, medya okuryazarlığı gibi çeşitli konular ders müfredatına zorunlu olarak eklenmeli ve alanında uzman kişiler tarafından çocuklar ile ebeveynler bilgilendirilerek, medyada ortamında maruz kalınan içerikler karşısında bilinç seviyesi yüksek bir toplum oluşturmak amaç edinilmelidir.

\section{Kaynakça}

Akbayır, M., Dumlu A. (2017). "Bir Göstergebilimsel Analiz Örneği: The Watchtower Of Turkey", International Congress Of Eurasian Social Sciences (ICOESS), Antalya, Türkiye.

Aktan, E. (2018). Üniversite Öğrencilerinin Sosyal Medya Bağımlılık Düzeylerinin Çeşitli Değişkenlere Göre İncelenmesi. Erciyes İletişim Dergisi, 5 (4), 405-421.

Atak, M. (2020). Sanal Dünya Sarmalında Gençlik. Avrasya Sosyal ve Ekonomi Araştırmaları Dergisi, 7 (9), 199-209.

Barthes, R. (2014). Çağdaş Söylenler, Çeviri: Tahsin Yücel. 4. Baskı. İstanbul: Metis Yayıncilik. 
Büyükgebiz Koca, E., ve Tunca, M.Z. (2020). İnternet ve Sosyal Medya Bağımlılığının Öğrenciler Üzerindeki Etkilerine Dair Bir Araştırma. Alanya Akademik Bakış, 4(1), Sayfa No. 77-103.

Çakı, C. (2018). Mitinglerin Propagandadaki Rolü: Nürnberg Mitinglerine Ait Fotoğrafların Göstergebilimsel Analizi. Maltepe Üniversitesi İletişim Fakültesi Dergisi, 5 (1), 59-79.

Çakmak, V. (2018). İletişim Kaygısı ve Sosyal Medya. Konya Eğitim Yayınevi. 1. Bask1.

Çalışkan, M. ve Mencik, Y. (2015). Değişen Dünyanın Yeni Yüzü. Akademik Bakış Dergisi. Sayı:50.

Çetin, E. (2015). Sosyal Paylaşım Ağlarında Fotoğraf, Yer/Mekân, Bildirim Paylaşımları ve Mahremiyet: Facebook Örneği, Uluslararası Sosyal Araştırmalar Dergisi. Cilt: 8 Sayı: 41: 779-788.

Çetinöz, N. (2013). Yeni İletişim Teknolojileri, Sosyal Medya. T.C. Anadolu Üniversitesi Yayın No: 2925.

Çîftçï, H. (2018). Üniversite Öğrencilerinde Sosyal Medya Bağımlılı̆̆ı. Manas Sosyal Araştırmalar Dergisi, 7 (4), 417-434.

Çobaner, A.A. (2013). Sağlık İletişiminde Korku Öğesinin Kullanımı: Sigara Paketlerinde Kullanılan Sigara Karşıtı Görsellerin Göstergebilimsel Analizi. İletişim Kuram ve Araştırmaları Dergisi, 37, 211-235.

Demirtaş, H., Özer, N. (2015). Eleştirel Kuram Açısından Eğitim ve Eğitim Yönetimi Journal of Teacher Education and Educators. 4(2): 206-227.

Dikmen, E. (2016). Türkiye'de Televizyon Yayıncılığının Yeni Medya Yapılanması. Televizyon ve Teknoloji Ekseninde Eleştirel Bir Değerlendirme. Doktora Tezi, Ankara Üniversitesi Sosyal Bilimler Enstitüsü.

Erdoğan, İ. (2014). Haber Çerçeveleme: Kuram ve Tipoloji. Marmara İletişim Dergisi, $13(13), 35-52$.

Fuchs, C. (2020). Sosyal Medya Eleştirel Bir Giriş. Nota Bene Yayınları. 2. Baskı. Çeviri: Diyar Saraçoğlu ve İlker Kalaycı.

Gökbel, Ç. (2018). Bir Popüler Kültür Masalı: Narcos Dizisine Eleştirel Bir Bakış. SDÜ İfade, 1 (1), 62-86.

Güngör, N. (2016). İletişim Kuramlar, Yaklaşımlar. Ankara: Siyasal Kitabevi 3. Baskı.

Hazar Ç. M (2011). Sosyal medya bağımlılı̆̆1-bir alan çalışması. İletişim Kuram ve Araştırma Dergisi, 0(32), 151-175.

İdris, M. (2017). Çocukluğun Dijitalleşmesi Çocuğun Dijital Zehirlenmesi. TRT Akademi Dergisi Cilt: 2, Sayı:4. 
Kavut, S. (2018). Goffman'ın benlik sunumu kuramı bağlamında sosyal medyada kimlik inşası: Instagram üzerine bir araştırma. Nosyon: Uluslararası Toplum ve Kültür Çalışmaları Dergisi. 1, 1-12.

Kurşun, H. (2017). Medya ve Şiddet Medyadaki Şiddet Olgusunun Toplumsal Hayata Yansıması Hakkında Niceliksel Araştırma: Gaziantep İl Örneği, 2016. Yüksek Lisans Tezi, Maltepe Üniversitesi Sosyal Bilimler Enstitüsü.

Küçük Durur, E. (2012). İnşacı Yaklaşım İçinde Çerçeveleme Kuramı ve Haberin Çerçevelenişi. Atatürk İletişim Dergisi, (2), 21-31.

Laloğlu, P. (2017). Göstergebilimsei Bir Yaklaşımla Misafir Odası Analizi. Folklor/Edebiyat, Sayı:91, 105-123.

Mutlu, B. ve Bazarcı, S. (2016). Marka İş birlikleri İçin Yeni Bir Alan: Youtube İçerik Üreticileri ve Kanal Toplulukları Üzerine Netnografik Bir Araştırma, Akdeniz İletişim Dergisi.

Netflix, A. (2021). Netflix Tarihçesi https://about.netflix.com/trr Erişim tarihi: 16.11.2021.

Netflix, B. (2021). https://www.netflix.com/tr/ Erişim tarihi: 16.11.2021.

Nuran, B.M. (2015). Geleneksel Medya ve Yeni Medya etkileşiminin Gezi Park1 Gösterileri Bağlamında İncelenmesi, Yüksek Lisans Tezi, Beykent Üniversitesi Sosyal Bilimler Enstitüsü.

Okutan, B. (2014). Karikatürlerdeki Başörtülü Figürlerin Göstergebilimsel Analizi: Penguen Dergisi Örneği. Journal of Istanbul University Faculty of Theology, 0 (29), 9-38.

Özçetin, B. (2019). Kitle İletişim Kuramları: Kavramlar, Okullar, Modeller. İletişim Yayınları. 1. Bask1.

Saussure, F. (1985). Genel Dilbilim Dersleri. Çeviri: Berke Vardar, Ankara: Birey ve Toplum.

Savaş, S. (2015). Bütünleşik Kurumsal İletişimin Bir Unsuru Olarak Çerçeveleme. Akdeniz Üniversitesi İletişim Fakültesi Dergisi, (24), 148-167.

Tuncer, H. (2018). İnternet Dizileri ve Televizyon Dizilerinin Sosyal Medya Kullanimı Açısından Karşılaştırılması. Yüksek Lisans Tezi, İstanbul Üniversitesi Sosyal Bilimler Enstitüsü.

Tutgun-Ünal, A. (2015). Sosyal Medya Bağımlılığı: Üniversite Öğrencileri Üzerine Bir Araştırma. Doktora Tezi, Marmara Üniversitesi Sosyal Bilimler Enstitüsü.

Türk, M.S. (2017). Görünür Değilsen Yoksun.

https://www.academia.edu/32461251/G\%C3\%96R\%C3\%9CN\%C3\%9CR DE\%C4 \%9E\%C4\%B0LSEN YOK SUN Erişim tarihi: 28.10.2021. 
Unicef. (2017). Dünya Çocuklarının Durumu 2017, Dijital bir Dünyada Çocuklar. https://www.unicef.org/turkey/raporlar/d\%C3\%BCnya-\%C3\%A7ocuklar\%C4\%B 1n\%C4\%B1n-durumu-2017-dijital-bir-d\%C3\%BCnyada-\%C3\%A7ocuklar Erişim tarihi: 01.11.2021.

Vural, Z.B.A. ve Bat, M. (2010). Yeni Bir İletişim Ortamı Olarak Sosyal Medya: Ege Üniversitesi İletişim Fakültesine Yönelik Bir Araştırma. Yaşar Üniversitesi E-Dergisi, 5 (20), 3348-3382.

Yaylagül, L. (2006). Kitle İletişim Kuramları Egemen ve Eleştirel Yaklaşımlar. Dipnot Yayınları 1.Bask1.

Yazıcı, F. ve Temel, M. (2020). Dijital Sorunlara İlişkin Eğitici Kısa Filmlere Eleştirel Bir Bakış. Erciyes İletişim Dergisi, 7 (1), 395-414.

Yetkiner, B. ve Öztürk, B. (2020). Kullanımlar ve Doyumlar Yaklaşımı Bağlamında İnönü Üniversitesi İletişim Fakültesi Öğrencilerinin Tik Tok Kullanımı. Iğdır Üniversitesi Sosyal Bilimler Dergisi, 24, s.215-235.

Zengin, D. (2021). Netflix'in abone sayısı yılın 3. çeyreğinde 'Squid Game' ile beklenenden çok artt. https://www.aa.com.tr/tr/kultur-sanat/netflixin-abone-sayisi-yilin-3-ceyreginde-s quid-game-ile-beklenenden-cok-artti/2397109 Erişim tarihi: 16.11.2021. 